\title{
Sistem Informasi Pengolahan Data Penyediaan Air dan Sanitasi Masyarakat (PAMSIMAS) berbasis Web
}

\author{
Acep Irham Gufroni ${ }^{1)}$, Cecep Muhamad Sidik Ramdani ${ }^{2)}$, Haikal Millah ${ }^{3)}$, Miftahul Habib \\ Fachrurozi 4), Andi Nur Rachman 5)
}

Jurusan Informatika, Fakultas Teknik, Universitas Siliwangi

Jl Siliwangi No24, Tasikmalaya, 46115, Indonesia

Email:acep@unsil.ac.id ${ }^{1)}$, cecepmuhamad@unsil.ac.id ${ }^{2)}$,haikal@unsil.ac.id ${ }^{3)}$, miftahul.habib@unsil.ac.id ${ }^{4)}$,andy.rachman@unsil.ac.id ${ }^{5)}$

\begin{abstract}
ABSTRAK
Tersaedianya air bersih merupakan harapan bagi masyarakat untuk memenuhi kebutuhan sumber minum dan tersedianya sanitasi yang layak akan mencegah berbagai penyakit. Maka pemerintah bekerjasama dengan desa dalam Penyediaan Air Minum dan Sanitasi Berbasis Masyarakat (PAMSIMAS). Program PAMSIMAS bertujuan untuk meningkatkan jumlah fasilitas air bersih pada masyarakat diwilayah yang dalam kalangan tingkat pendapatan ekonomi rendah. Dalam program PAMSIMAS di Desa Tigaherang Kecamatan Rajadesa Kabupaten Ciamis diperlukan langkah sosialisai kepada masyarakat untuk memberikan sebuah pemahaman tentang air bersih dan sanitasi, adanya pemantauan penggunaan air bersih dan transparansi program PAMSIMAS. Untuk menunjang pelaksanaannya maka diusulkan sebuah rancang bangun Aplikasi Sistem Informasi Penyediaan Air Minum dan Sanitasi Berbasis Masyarakat (PAMSIMAS) berbasis Web. System Informasi ini di harapkan mampu mengoptimalkan kinerja dan pelayanan air bersih bagi masyarakat.
\end{abstract}

Kata kunci: Masyarakat, Program PAMSIMAS (penyediaan air minum dan sanitasi berbasis masyarakat), Sistem Informasi.

\section{ABSTRACT}

The availability of clean water is a hope for the community to meet the needs of drinking sources and the availability of proper sanitation will prevent various diseases. So the government collaborates with villages in providing Community Based Drinking Water and Sanitation (PAMSIMAS). The PAMSIMAS program aims to increase the number of clean water facilities for communities in areas with low economic income levels. In the PAMSIMAS program in Tigaherang Village, Rajadesa District, Ciamis Regency, socialization steps are needed to the community to provide an understanding of clean water and sanitation, monitoring of clean water use and transparency of the PAMSIMAS program. To support its implementation, a Web-based Information System for Water Supply and Sanitation (PAMSIMAS) application design is proposed. This information system is expected to be able to optimize the performance and service of clean water for the community.

Keywords: Community, PAMSIMAS Program (community based drinking water supply and sanitation), Information System.

\section{Pendahuluan}

Pemerintah mencanangkan pembangunan pemerataan untuk mendapatkan sumber air bersih dalam Rencana Pembangunan Jangka Menengah Nasional (RPJMN). Program pemerintah tersebut didukung oleh berbagai pihak dari pemerintah pusat dan pemerintah daerah untuk meningkatkan akses masyarakat dalam mendapatkan sumber air minum dan sanitasi yang layak supaya terhidar dari berbagiamacam penyakit, seperti kolera, diare dan penyakit lain yang timbul akibat dari 
kurangnya pemahaman masyarakat akan pentingnya tersedia fasilitas pamsimas yang akan membantu untuk memenuhui kebutuhan dalam kehidupan.

Program pamsimas ini bertumpu pada kesiapan masyarakat dalam berpartisipasi untuk saling gotong royong dalam menjalankan program pemerintah pamsimas. Mulai dari penataan infrastruktur, penglolaan penggunaan dan perawatan dari fasilitas yang sudah dibangun.

Pamsimas merupakan pelayanan publik, berdasarkan Undang-Undang No. 23 Tahun 2014 tentang Pemerintahan Daerah, pelayanan air minum dan sanitasi menjadi kewajiban Pemerintah Daerah untuk memenuhi Standar Pelayanan Minimal (SPM).

Program Pamsimas penyediaan investasi fisik dalam bentuk sarana dan prasarana yang harus dibangun dan dikelola dengan baik, maupun investasi non-fisik dalam bentuk manajemen, teknis, dan pengembangan kapasitas untuk kemajuan masyarakat desa. Ruang lingkup Program Pamsimas secara umum terdiri dari lima komponen program yaitu pertama pemberdayaan masyarakat, kedua peningkatan perilaku higienis dan pelayanan sanitasi, ketiga penyediaan sarana air minum dan sanitasi, keempat pengelolaan dari program hibah pamsimas, kelima dukungan teknis dan manajemen pelaksanaan program pamsimas di desa tigaherang.

Karena berbasis masyarakat di perlukan peran atau partisipasi dari masyarakat itu sendiri sebagai pelaksana dan penerima manfaat dari program Pamsimas. Sosialisasi menjadi kegiatan dasar untuk masyarakat Desa Tigaherang Kecamatan Rajadesa Kabupaten Ciamis sebagai penerima bantuan yang bertujuan untuk pemberdayaan masyarakat, peningkatan perilaku higienis, dan pelaksana teknis.

Program pamsimas ini perlu peran aktif dari pastisipasi masyarakat dimana, menurut Davis, (1986) mendefinisikan partisipasi sebagai berikut "participation is defined as mental and emotional involvement of persons in group situations that encourage them to contribute to group goals and share responsibility for them". Sedangkan masyarakat menurut Ralph Linton (1996), masyarakat adalah setiap kelompok manusia yang telah hidup dan bekerja sama cukup lama sehingga mereka dapat mengatur diri sendiri dan menganggap diri mereka sebagai suatu kesatuan sosial dengan batas-batas yang dirumuskan dengan jelas.

Untuk mendukung kinerja dari program PAMSIMAS di Desa Tigaherang Kecamatan Rajadesa Kabupaten Ciamis diusulkan sebuah sistem berupa aplikasi berbasis web yang mana kegunaannya disamping sebagai alat sosialisasi bagi masyarakat juga untuk mengamati atau memantau penggunaan air bersih ketika program PAMSIMAS berjalan dan sebagai media transparansi antara pengelola dalam hal ini Kelompok Kerja Masyarakat (KKM) dengan pengguna air bersih atau masyarakat.

Dengan adanya sistem informasi Penyediaan Air Minum dan Sanitasi Berbasis Masyarakat (PAMSIMAS) berbasis web ini diharapkan data yang di proses dapat berguna, baik bagi pengelola yaitu Kelompok Kerja Masyarakat (KKM) maupun pengguna atau masyarakat dari program PAMSIMAS.

\section{Tinjauan Pustaka}

\subsection{Penyediaan Air Minum dan Sanitasi Berbasis Masyarakat (PAMSIMAS)}

PAMSIMAS kegiatan dibidang air minum dan sanitasi bagi masyarakat perdesaan dan dilaksanakan berbasis masyarakat. Secara lebih rinci PAMSIMAS bertujuan untuk:
a. Meningkatkan praktek hidup bersih dan sehat di masyarakat,
b. Meningkatkan jumlah masyarakat yang memiliki akses air minum.
c. Meningkatkan kapasitas masyarakat dan kelembagaan lokal.
d. Meningkatkan efektifitas dan kesinambungan jangka panjang. 
PAMSIMAS merupakan program pemerintah dengan dukungan Bank Dunia, untuk meningkatkan penyediaan air minum, sanitasi, dan meningkatkan derajat kesehatan masyarakat terutama dalam menurunkan angka penyakit diare (Barkah, 2013).

\subsection{Kelembagaan Program PAMSIMAS}

PAMSIMAS dilaksanakan pemerintah pusat melalui penyediaan bantuan ke tingkat desa, dengan didukung lembaga pelaksana program Departemen Kesehatan, Departemen Dalam Negeri dan Departemen Pendidikan Nasional. (Barkah, 2013).

Selain itu, pengelola bertanggung jawab menjamin tercapainya indikator kinerja. Pengelola program melakukan koordinasi program, tim teknis program dan Project Management Unit (PMU) Pusat. Kelembagaan masyarakat dan unit pelaksana struktur organisasi program di tingkat desa/kelurahan berbeda signifikan dengan struktur formal di tingkat pemerintah kabupaten/kota, provinsi dan pusat. PAMSIMAS mengutamakan representative, partisipatif, akuntabel dan dilaksanakan sepenuhnya oleh masyarakat, dengan kriteria anggota yang lebih mengutamakan kepercayaan masyarakat.

\section{Metodologi Penelitian}

Pengembangan sistem yang diterapkan untuk membuat Sistem Informasi Penyediaan Air Minum dan Sanitasi Berbasis Masyarakat (PAMSIMAS) berbasis Web yaitu menggunakan metode Prototype. Skema aplikasi melibatkan developer dan client bisa berinteraksi secara langsung dalam proses pembuatan aplikasi. Berikut adalah penjelasan dari tahapan yang dilakukan :

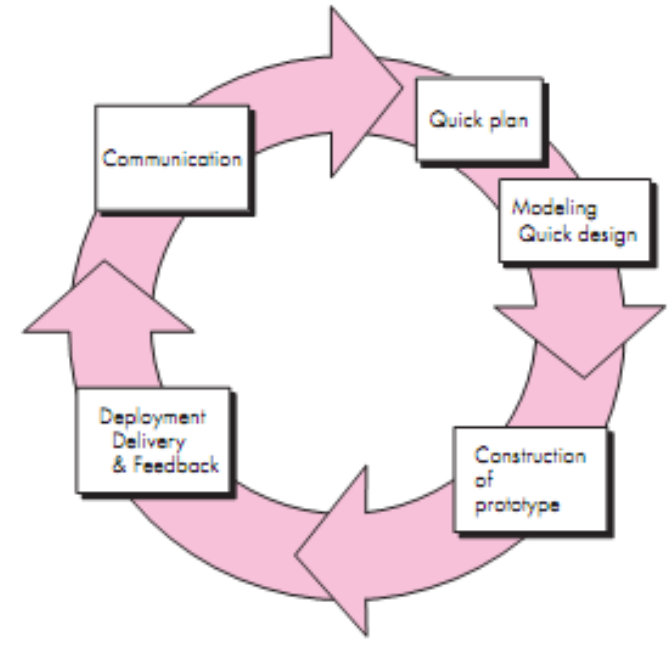

Gambar 1. Metode Prototype (Pressman , 2010)

1. Communication atau pengumpulan kebutuhan, mengambil data dengan cara berdiskusi dan studi literatur untuk program pamsimas di desa tigaherang.

2. Quick Plan atau Planning, melukan perancangan aplikasi sesuai dengan kebutuhan untuk menunjang program pamsimas.

3. Modelling Quick Design pembuatan model desain arsitektur aplikasi untuk program pamsimas dari mulai input data, proses dan output yang diharapkan untuk menunjang kebutuhan aplikasi.

4. Construction of Prototype, pembuatan sintak aplikasi.

5. Deployment Delivery and Feedback, pengujian aplikasi dan sosialisasi penggunaan aplikasi program pamsimas. 


\section{Hasil dan Pembahasan}

Aplikasi Sistem Informasi Penyediaan Air Mineral dan Sanitasi Berbasis Masyarakat (PAMSIMAS) berbasis Web di Desa Tigaherang Kecamatan Rajadesa Kabupaten Ciamis yang telah dibuat mempunyai beberapa menu sesuai dengan hak akses pengguna yang mengakses aplikasi. Hak akses untuk admin terdiri dari menu beranda admin, menu registrasi pengguna, dan menu penggunaan air. Sedangkan hak akses untuk user terdiri dari menu beranda, menu PAMSIMAS, dan menu cari.

Hak akses administrator menu beranda berfungsi untuk melihat halaman utama pada panel admin, menu registrasi pengguna berfungsi untuk menginputkan data pengguna PAMSIMAS, dan menu penggunaan air berfungsi untuk menginput data penggunaan air dari pengguna PAMSIMAS. Sedangkan hak akses user menu beranda digunakan untuk melihat halaman awal mengenai program desa di Desa Tigaherang, menu PAMSIMAS berfungsi untuk melihat informasi mengenai program PAMSIMAS, dan menu cari berfungsi untuk mencari pengguna program PAMSIMAS yang telah di inputkan oleh admin.

\subsection{Arsitektur Aplikasi}

Berikut adalah rancangan arsitektur aplikasi yang akan dibangun dan proses aliran data pada aplikasi sistem informasi PAMSIMAS dengan melibatkan pengguna yang berinteraksi dengan sistem:

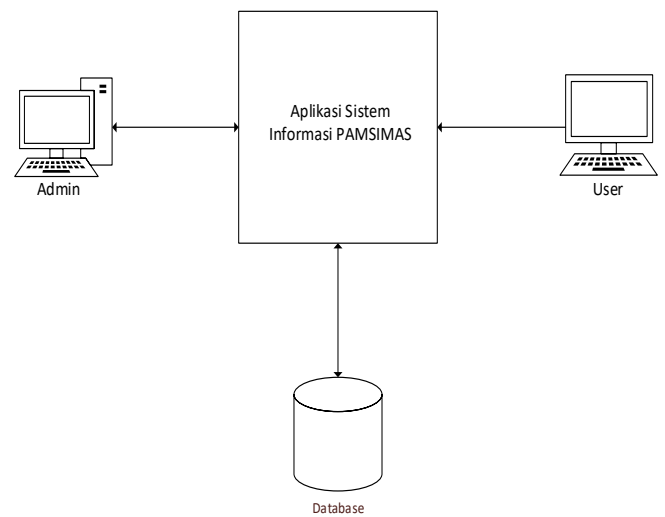

Gambar 2. Arsitektur Aplikasi

\subsection{Pemodelan Fungsional}

Pendekatan yang digunakan dalam membuat aplikasi yaitu lebih difokuskan pada perancangan aplikasi. Penjelasan dari pemodelan fungsional disusun dalam masing-masing diagram.

\subsubsection{Diagram Konteks}

Diagram konteks pada penelitian ada dua entitas yaitu, administrator, dan user. User merupakan pengguna yang hanya mendapatkan hak akses penerima informasi program PAMSIMAS. Administrator merupakan pemegang hak akses penuh terhadap aplikasi. Berikut gambar diagram konteks:

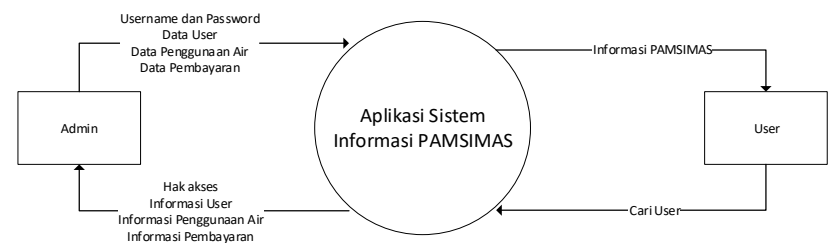

Gambar 3. Diagram Konteks 


\subsection{Implementasi Perangkat Lunak}

Aplikasi Sistem Informasi Penyediaan Air Mineral dan Sanitasi Berbasis Masyarakat (PAMSIMAS) berbasis Web yang telah dibangun terdiri dari halaman administrator (backend) dan halaman pengguna (frontend) yang dapat diakses oleh user.

\subsubsection{Tampilan Aplikasi}

Berikut ini merupakan tampilan dari halaman backend aplikasi yang telah dibangun:

1. Login Admin

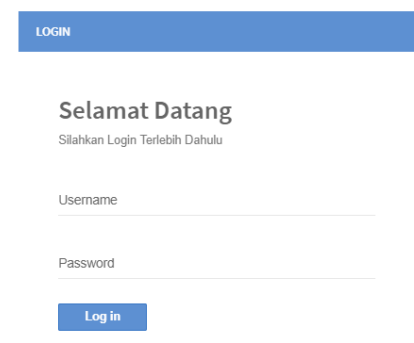

Gambar 4. Tampilan login Admin

Gambar diatas merupakan tampilan login untuk admin yang telah dibangun.

2. Halaman Utama Admin

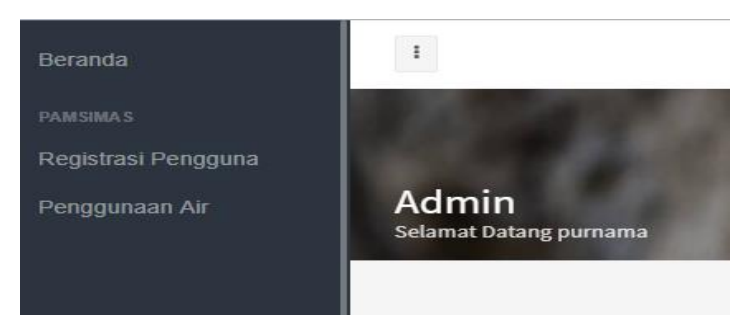

Gambar 5. Tampilan Utama Admin

Gambar diatas merupakan tampilan halaman utama admin dari aplikasi sistem informasi PAMISMAS yang telah dibangun. Yang mana terdapat menu beranda, registrasi pengguna, dan penggunaan air.

3. Halaman Registrasi Pengguna

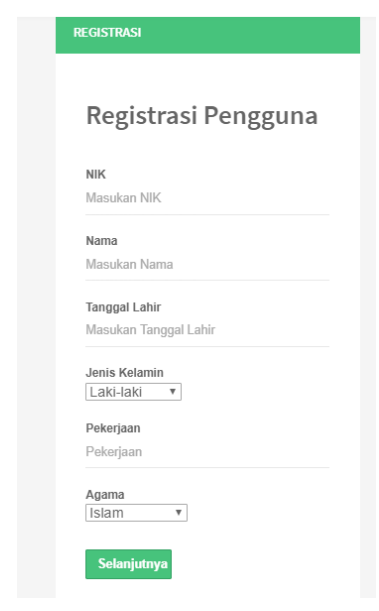

Gambar 6. Tampilan Registrasi Pengguna 
Gambar dari halaman registrasi pengguna berupa data KTP dan KK untuk data pengguna PAMSIMAS.

4. Halaman Pengolahan Penggunaan Air

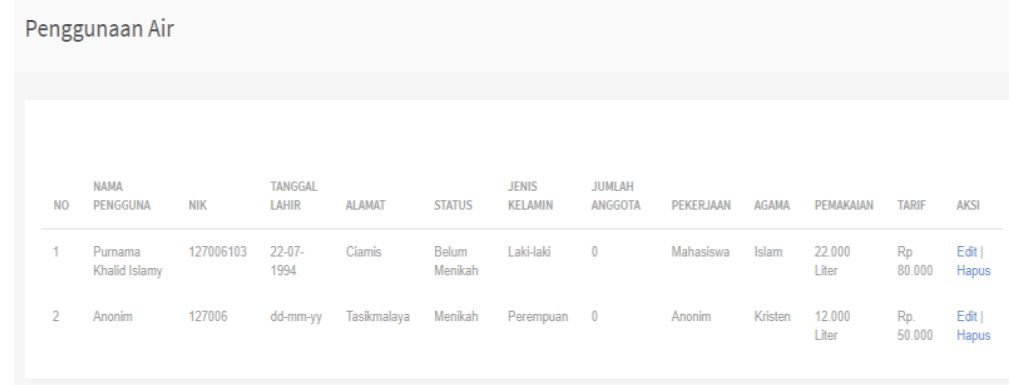

Gambar 7. Tampilan Pengolahan Penggunaan Air

Gambar diatas merupakan tampilan pengolahan data penggunaan air dari pengguna PAMSIMAS.

\subsection{Pembahasan dan Evaluasi}

Aplikasi sistem informasi Penyediaan Air Mineral dan Sanitasi Berbasis Masyarakat (PAMSIMAS) dapat mendukung proses sosialisasi kepada pengguna atau masyarakat mengenai program ini. Menjadi media transparansi antara pengelola atau Kelompok Kerja Masyarakat (KKM) dengan masyarakat dan meningkatkan kapasitas layanan untuk pengembangan program pamsimas secara luas.

\section{Daftar Pustaka}

Agung, Kurniawan. (2005). Transformasi Pelayanan Publik. Yogyakarta: Pembaruan.

Badan Pengelola Sarana Prasarana Air Minum dan Sanitasi (2012). Tirtamulya.

Barkah, Sanjaya. (2013). Evaluasi Program Pamsimas (Penyediaan Air Minum dan Sanitasi Berbasis Masyarakat), Fakultas Ilmu Sodsial dan Ilmu Politik, Universitas Diponegoro, Semarang. Dalam Skripsi Jurusan Ilmu Pemerintahan.

Hartono, Jogiyanto. (1999). Analisa dan desain Sistem Informasi : Pendekatan Terstruktur Teori dan Praktek Aplikasi Bisnis. Yogyakarta : Penerbit Andi Offset

Nugroho, Bunafit. (2008). Aplikasi Pengembangan Web Dinamis dengan PHP dan MySQL. Yogyakarta: Penerbit Gaya Media.

Oetomo, Budi Sutedjo Dharma. (2002),. Perencanaan dan Pengembangan Sistem Informasi. Yogyakarta : Penerbit Andi.

Soetomo. (2011). Pemberdayaan Masyarakat Mungkin Muncul Anisetesisnya. Yogyakarta : Pustaka Pelajar.

Sumodiningrat, Gunawan, (1997). Pembangunan Daerah dan Pemberdayaan Masyarakat, PT. Bina Rena Pariwara.

Suryadi, Kadarsah. (1998). Sistem Pendukung Keputusan. Bandung : Penerbit Remaja Rosdakarya Offset.

Susiyanto, Didit. (2009). Pendekatan CLST (Community Lead Total Samitation) dalam Per ubahan Prilaku Kesehatan Pada Masyarakat (Studi Kasus : Perubahan perilaku BAB Mas yarakat Di Desa Kenongo Kecamatan Gucialit Kabupaten Lumajang); Jember : Penerbitan Universitas Jember.

Roger S. Pressman, P. D. (2010). Rekayasa Perangkat Lunak : Pendekatan Praktisi . Yogyakarta: Andi. 